\title{
Experimental and Theoretical Studies of the Redox Potentials of Cyclic Nitroxides
}

\author{
James P. Blinco, ${ }^{\dagger}$, Jennifer L. Hodgson, ${ }^{\dagger, \S}$ Benjamin J. Morrow, ${ }^{\dagger, \ddagger}$ James R. Walker, ${ }^{\dagger, \star}$ \\ Geoffrey D. Will, ${ }^{\ddagger}$ Michelle L. Coote ${ }^{\dagger, \S}$ and Steven E. Bottle ${ }^{*, \dagger, \ddagger}$ \\ Australian Research Council Centre of Excellence for Free Radical Chemistry and Biotechnology, School \\ of Physical and Chemical Sciences, Queensland University of Technology, GPO Box 2434, \\ Brisbane, Queensland, 4001, Australia, and Research School of Chemistry, Australian National University, \\ Canberra, ACT, 0200, Australia \\ s.bottle@qut.edu.au
}

Received May 20, 2008

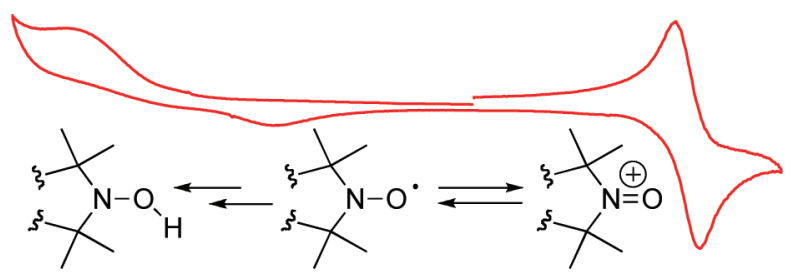

The redox potentials of 25 cyclic nitroxides from four different structural classes (pyrrolidine, piperidine, isoindoline, and azaphenalene) were determined experimentally by cyclic voltammetry in acetonitrile, and also via high-level ab initio molecular orbital calculations. It is shown that the potentials are influenced by the type of ring system, ring substituents and/or groups surrounding the radical moiety. For the pyrrolidine, piperidine, and isoindolines there is excellent agreement (mean absolute deviation of 0.05 $\mathrm{V}$ ) between the calculated and experimental oxidation potentials; for the azaphenalenes, however, there is an extraordinary discrepancy (mean absolute deviation of $0.60 \mathrm{~V}$ ), implying that their one-electron oxidation might involve additional processes not considered in the theoretical calculations. This recently developed azaphenalene class of nitroxide represents a new variant of a nitroxide ring fused to an aromatic system and details of the synthesis of five derivatives involving differing aryl substitution are also presented.

\section{Introduction}

Reactive free radicals may play a detrimental role in biological systems with evidence they contribute toward aging, ischemia, inflammatory and autoimmune diseases, as well as atherosclerosis. ${ }^{1}$ The general conditions under which these reactions take place have been termed "oxidative stress" and this refers to a situation of cellular damage resulting from accumulation of reactive oxygen species (ROS). ROS and other free radicals are constantly formed in the human body as a part of normal metabolic processes. However, when produced in excess, these ROS can lead to tissue injury and even cell death. Nitroxides, which are persistent, kinetically stable free radicals, have been widely studied as potential antioxidants against such reactive species due to their unique ability to trap carbon-,

\footnotetext{
* Corresponding author. Phone: +61-7-3138-1356. Fax: +61-7-3138-1804

Australian Research Council Centre of Excellence for Free Radical Chemistry and Biotechnology.

* Queensland University of Technology.

\& Australian National University.

(1) Gutteridge, J. M. Free Radical Res. Commun. 1993, 19, 141.
}

sulfur-, and phosphorus-centered radicals, as well as interact with oxygen-centered radicals via one-electron redox processes.

Oxidation and reduction processes involving nitroxides are of particular interest as both appear to be biologically relevant. Mitchell et al. ${ }^{2,3}$ showed that the nitroxide 2-ethyl-2,5,5trimethyl-3-oxazolidin-1-oxyl was able to protect mammalian cell lines against superoxide $\left(\mathrm{O}_{2}{ }^{--}\right)$by acting as a superoxide dismutase mimic. This result was rationalized by the proposal that the nitroxide was first reduced by superoxide to a hydroxylamine and subsequently reoxidised to regenerate the nitroxide in a catalytic cycle yielding $\mathrm{O}_{2}$ and $\mathrm{H}_{2} \mathrm{O}_{2}$ (mechanism 1 , Scheme 1). Other piperidine-based nitroxides such as 2,2,6,6-tetramethylpiperidin-1-yloxyl and 4-hydroxy-2,2,6,6-tetramethylpiperidin-1-yloxyl have been shown to catalyze the dismutation of superoxide in a process thought to involve the nitroxide

(2) Mitchell, J. B.; Samuni, A.; Krishna, M. C.; DeGraff, W.; Ahn, M. S.; Samuni, U.; Russo, A. Biochemistry 1990, 29, 2802.

(3) Samuni, A.; Krishna, M. C.; Mitchell, J. B.; Collins, C. R.; Russo, A. Free Radical Res. Commun. 1990, 9, 241. 


\section{SCHEME 1. SOD Mechanisms of Cyclic Nitroxides}

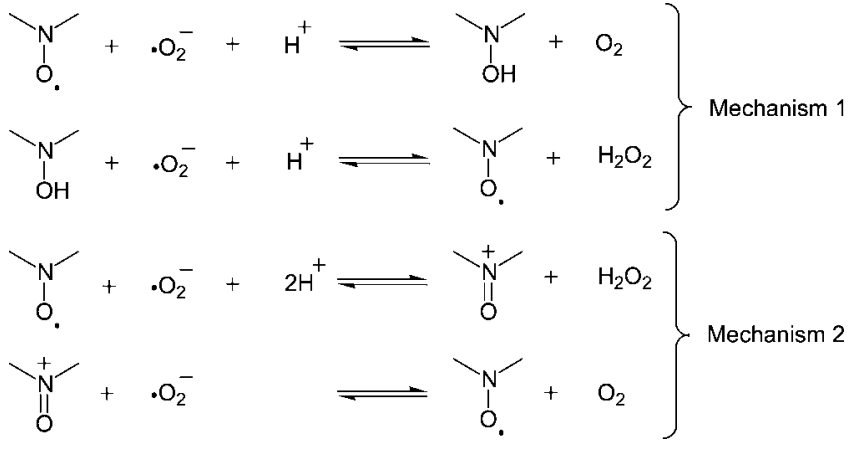

TABLE 1. Experimental Redox Potentials $(V)$ of the Nitroxides Studied $^{a}$

\begin{tabular}{|c|c|c|c|c|c|c|c|}
\hline \multirow[b]{2}{*}{ compd } & \multicolumn{5}{|c|}{ oxidation } & \multicolumn{2}{|c|}{ reduction } \\
\hline & $E_{\mathrm{pa}}$ & $E_{\mathrm{pc}}$ & $E^{\mathrm{o} b}$ & $E_{\mathrm{pa}}-E_{\mathrm{pc}}$ & $i_{\mathrm{pa}} / i_{\mathrm{pc}}{ }^{c}$ & $E_{\mathrm{pc}}$ & $E_{\mathrm{pa}}$ \\
\hline 1 & 0.753 & 0.651 & 0.702 & 0.102 & 0.94 & -1.450 & \\
\hline $2 a$ & 0.631 & 0.522 & 0.577 & 0.109 & 1.10 & -2.335 & -0.455 \\
\hline $2 b$ & 0.692 & 0.608 & 0.65 & 0.084 & 0.92 & -1.518 & \\
\hline $2 c$ & 0.649 & 0.557 & 0.603 & 0.092 & 0.91 & -1.592 & \\
\hline 2d & $0.843(0.698)^{d}$ & 0.734 & 0.789 & 0.109 & 0.55 & -2.079 & \\
\hline $3 a$ & 0.775 & 0.696 & 0.736 & 0.079 & 0.85 & -1.672 & -0.910 \\
\hline $3 \mathbf{b}$ & 0.866 & 0.778 & 0.822 & 0.088 & 0.93 & -2.432 & \\
\hline $3 c$ & 0.94 & 0.863 & 0.902 & 0.077 & 0.86 & -1.915 & \\
\hline $3 d$ & $0.861(0.654)^{d}$ & 0.796 & 0.829 & 0.065 & 0.53 & -1.787 & \\
\hline $3 e$ & $0.946(0.722)^{d}$ & 0.87 & 0.908 & 0.076 & 0.55 & -1.898 & \\
\hline $4 a$ & 0.822 & 0.719 & 0.771 & 0.103 & 1.05 & -2.192 & -0.911 \\
\hline $4 b$ & 0.861 & 0.781 & 0.821 & 0.08 & 0.99 & -1.279 & \\
\hline $4 c$ & 0.89 & 0.808 & 0.849 & 0.082 & 0.93 & -0.996 & \\
\hline $4 d$ & 0.796 & 0.702 & 0.749 & 0.094 & 0.92 & -1.562 & \\
\hline $4 e$ & 0.808 & 0.705 & 0.757 & 0.103 & 0.83 & -2.153 & \\
\hline $4 f$ & 0.775 & 0.69 & 0.733 & 0.085 & 1.02 & & \\
\hline $4 \mathrm{~g}$ & 0.878 & 0.772 & 0.825 & 0.106 & 0.98 & -2.160 & -0.633 \\
\hline $4 h$ & 0.899 & 0.814 & 0.857 & 0.085 & 0.95 & -2.149 & -0.718 \\
\hline $4 i$ & 0.866 & 0.767 & 0.817 & 0.099 & 0.98 & -1.966 & -0.778 \\
\hline $4 j$ & 0.929 & 0.82 & 0.875 & 0.109 & 0.88 & & \\
\hline $4 \mathbf{k}$ & $0.782(1.357)^{d}$ & 0.652 & 0.717 & 0.13 & 0.91 & -2.128 & -0.783 \\
\hline $5 \mathbf{a}$ & 0.777 & 0.68 & 0.729 & 0.097 & 0.89 & -2.262 & \\
\hline $5 b$ & 1.069 & 0.984 & 1.027 & 0.085 & 0.83 & -1.638 & \\
\hline 6 & 0.858 & 0.773 & 0.816 & 0.085 & 0.83 & -2.048 & \\
\hline 7 & 0.837 & 0.749 & 0.793 & 0.088 & 0.93 & -1.948 & -1.136 \\
\hline
\end{tabular}

${ }^{a} 0.1 \mathrm{M}$ TBAF in acetonitrile, $\mathrm{Pt}$ electrode, $\mathrm{Ag} / \mathrm{AgCl}$ electrode, sweep rate $0.15 \mathrm{~V} \mathrm{~s} \mathrm{~s}^{-1} \cdot{ }^{b} E^{\mathrm{o}}=\left(E_{\mathrm{pc}}+E_{\mathrm{pa}}\right) / 2 .{ }^{c}\left(i_{\mathrm{pa}} / i_{\mathrm{pc}}\right)=\left[\left(i_{\mathrm{pa}}\right)_{0} / i_{\mathrm{pc}}\right]+$ $\left[0.485\left(i_{\mathrm{sp}}\right)_{0} / i_{\mathrm{pc}}\right]+0.086$, where $\left(i_{\mathrm{pa}}\right)_{0}$ is the uncorrected anodic current and $\left(i_{\mathrm{sp}}\right)_{0}$ is the current at the switching potential. ${ }^{8}{ }^{d}$ Secondary oxidation not related to the nitroxide moiety.

oxidizing to the oxammonium cation. ${ }^{4}$ The oxammonium cation is then reduced back to the nitroxide also yielding $\mathrm{O}_{2}$ and $\mathrm{H}_{2} \mathrm{O}_{2}$ (mechanism 2). The exact nature of the mechanism involved in this dismutation may be dependent on the nature of the redox pairs involved in the process. In this regard, cyclic voltammetry measurements of the redox potentials of the nitroxides may provide insight into the factors that govern this dismutation and could provide insight into the mechanism of action of nitroxides in vivo. The ability to predict the redox potentials of differently substituted and various ring classes of nitroxides would also be of value to help define the best synthetic targets for potential biologically relevant antioxidants.

Previously, we were able to predict the redox potentials for 54 cyclic nitroxides using high-level ab initio calculations. ${ }^{5}$ Although these calculations correlated well with the available

(4) Krishna, M. C.; Grahame, D. A.; Samuni, A.; Mitchell, J. B.; Russo, A. Proc. Natl. Acad. Sci. U.S.A. 1992, 89, 5537.

(5) Hodgson, J. L.; Namazian, M.; Bottle, S. E.; Coote, M. L. J. Phys. Chem. A 2007, 111, 13595. experimental results, of the 54 compounds assessed computationally, only 7 aliphatic derivatives were able to be directly compared with literature data. In this study we report oxidation and, where possible, reduction potentials of 25 nitroxides (shown in Scheme 2) measured via cyclic voltammetry (Table 1). The data are then compared with those of high-level ab initio molecular orbitals for the same compounds under the experimental conditions of the present work, thereby providing an opportunity to test the theory underpinning the ab initio calculations.

\section{Synthetic Results}

The treatment of 2-benzyl-1,1,3,3-tetramethyl-2,3-dihydro2-azaphenalene (3a', designated as ' to indicate its precursor relationship to the nitroxide 3a) with $\mathrm{HNO}_{3}$ in the presence of $\mathrm{H}_{2} \mathrm{SO}_{4}$ selectively nitrates the 6 position of the azaphenalene ring in high yield. This nitration is highly dependent on the reaction temperature. When the reaction is carried out at room temperature, quantitative mononitration can be achieved in 150 min. Raising the reaction temperature to $60^{\circ} \mathrm{C}$ results in double nitration of the azaphenalene ring, yielding the 6,7-dinitroamine $\mathbf{3 c}^{\prime}$. No nitration of the benzyl ring was observed under these conditions. Both the mono- and dinitro analogues were able to be debenzylated and oxidized to the corresponding nitroxides, $\mathbf{3 b}$ and $\mathbf{3 c}$, in one step with use of mCPBA.

Hydrogenation of $\mathbf{3 b}$ in the presence of $\mathrm{Pd} / \mathrm{C}$ catalyst followed by treatment with $\mathrm{PbO}_{2}$ to partially reoxidize the resultant aminohydroxylamine to the nitroxide yielded the amino analogue 3d. Although this compound is stable in air after preparation, when stored, even in an inert environment at low temperatures, a small amount of highly colored degradation product is formed. A more stable dimethylamino analogue $\mathbf{3 e}$ could be synthesized from this compound via a basic methylation by using methyl iodide in a sealed vessel. Attempts to reduce the dinitro compound $\mathbf{3 c}$ under similar conditions to those used for $\mathbf{3 b}$ to give the 6,7-diamino analogue failed as the product formed during hydrogenation rapidly decomposed on workup.

The synthetic route to nitroxides $\mathbf{4 e}$ and $\mathbf{4 f}$ (Scheme 4) was developed from the established procedures for methanolysis by Capdevielle and Maumy. ${ }^{6}$ Starting with $\mathbf{4 g}$ it was possible to carry out copper(I)-catalyzed aryl bromide substitution by methoxide ion to form the methylaryl ether $4 \mathbf{e}$ in good yield. Analogous synthesis of the dimethoxy compound $\mathbf{4} \mathbf{f}$ from the nitroxide $\mathbf{4 h}$ proved troublesome. However, the methanolysis could be carried out on the secondary amine analogue $\mathbf{4} \mathbf{h}^{\prime}$, which subsequently could then be oxidized to the nitroxide $\mathbf{4 f}$ with mCPBA.

Compounds $\mathbf{4 d}$ and $\mathbf{4 i}$ were synthesized via a diazonium cation intermediate that was prepared in situ from $\mathbf{4 k}$ and $\mathrm{NaNO}_{2}$ in an acidic aqueous environment.

The phenol 4d was generated by simple heating of the aqueous solution once sufficient time had been allowed for the diazotation to take place (Scheme 5). The yield of the reaction was moderate $(41 \%)$ though alternative procedures with $\mathrm{H}_{2} \mathrm{SO}_{4}$ instead of $\mathrm{HCl}$ as the mineral acid did not improve the outcome.

The synthesis of $\mathbf{4} \mathbf{i}$ requires quenching the diazonium solution with an aqueous solution of KI and CuI. On a small scale $(<100$ $\mathrm{mg}$ ) the addition of the diazonium salt to the iodide solution or vice versa did not affect the yield significantly. On larger scales

(6) Capdevielle, P.; Maumy, M. Tetrahedron Lett. 1993, 34, 1007. 
SCHEME 2. Nitroxides Investigated in Cyclic Voltammetry and Theoretical Studies<smiles>[R]C1C([R])C(C)(C)N([O-])C1(C)C</smiles>

$1 \mathrm{R}_{1}=\mathrm{COOH} \mathrm{R}_{2}=\mathrm{H}$<smiles>[R]C1([R])c2ccccc2C([R])([R])N1[O-]</smiles>

5a $\mathrm{R}=\mathrm{Et}$

b $\mathrm{R}=\mathrm{Ph}$<smiles>[R]C1CC(C)(C)N([O-])C(C)(C)C1</smiles><smiles>[R]C(=C)c1c([R])ccc2c1C(=C)C(C)(C)N([O])C2(C)C</smiles><smiles>[R]c1cc2c(cc1[R])C(C)(C)N([O-])C2(C)C</smiles>

3a $\mathrm{R}_{1}=\mathrm{H}$

$R_{2}=H \quad 4 a R_{1}=H \quad R_{2}=H$

b $\mathrm{R}=\mathrm{COOH} \quad$ b $\mathrm{R}_{1}=\mathrm{NO}_{2} \quad \mathrm{R}_{2}=\mathrm{H} \quad$ b $\mathrm{R}_{1}=\mathrm{COOH} \mathrm{R} \mathrm{R}_{2}=\mathrm{H}$

c $\mathrm{R}=\mathrm{OH} \quad$ c $\mathrm{R}_{1}=\mathrm{NO}_{2} \quad \mathrm{R}_{2}=\mathrm{NO}_{2} \quad$ c $\mathrm{R}_{1}=\mathrm{COOH} \mathrm{R}_{2}=\mathrm{COOH}$

d $\mathrm{R}=\mathrm{NH}_{2} \quad$ d $\mathrm{R}_{1}=\mathrm{NH}_{2} \quad \mathrm{R}_{2}=\mathrm{H} \quad$ d $\mathrm{R}_{1}=\mathrm{OH} \quad \mathrm{R}_{2}=\mathrm{H}$

e $R_{1}=N(M e)_{2} \quad R_{2}=H \quad$ e $R_{1}=O M e \quad R_{2}=H$

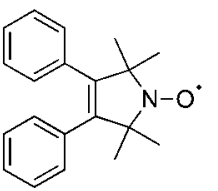

6

f $\mathrm{R}_{1}=\mathrm{OMe} \quad \mathrm{R}_{2}=\mathrm{OMe}$

g $\mathrm{R}_{1}=\mathrm{Br} \quad \mathrm{R}_{2}=\mathrm{H}$

h $\mathrm{R}_{1}=\mathrm{Br} \quad \mathrm{R}_{2}=\mathrm{Br}$

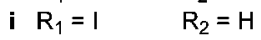

j $\begin{array}{ll}\mathrm{R}_{1}=\mathrm{NO}_{2} & \mathrm{R}_{2}=\mathrm{H} \\ \mathrm{R}_{1}=\mathrm{NH}_{2} & \mathrm{R}_{2}=\mathrm{H}\end{array}$

7

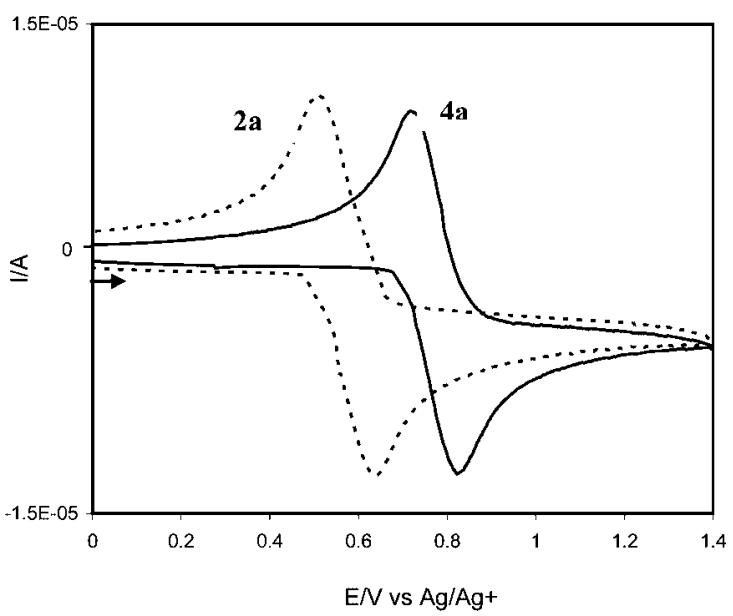

FIGURE 1. Cyclic voltammograms of the nitroxide/ $N$-oxoammonium couple of $\mathbf{2 a}(---)$ and $\mathbf{4 a}(-)$.

examples of the observed waves are shown in Figure 1. In all cases the nitroxides underwent a one-electron oxidation that corresponds to the formation of the $\mathrm{N}$-oxoammonium cation. The redox potentials, $E^{\mathrm{o}}$, of the oxidation of the nitroxide were estimated as half the sum of the anodic $\left(E_{\mathrm{pa}}\right)$ and cathodic $\left(E_{\mathrm{pc}}\right)$ peak potentials. The peak separation, $E_{\mathrm{pa}}-E_{\mathrm{pc}}$, ranged from 65 to $109 \mathrm{mV}$. These values are approaching the theoretical Nernstian value of $59 \mathrm{mV}$ indicating kinetic reversibility in the oxidations. The $i_{\mathrm{pa}} / i_{\mathrm{pc}}$ for the oxidation wave was approaching unity in all cases (except when an amino functionality was present) showing the nitroxide/oxoammonium cation couple is also thermodynamically reversible. The robustness of the nitroxides was also tested by cycling the unsubstituted parent structures $\mathbf{2 a}, \mathbf{3 a}$, and $\mathbf{4 a}$ more than 100 times each resulting in no change to the intensity of the $i_{\mathrm{pa}}$ values or shifting the $E_{\mathrm{pa}} /$ $E_{\mathrm{pc}}$ values.

Compounds $\mathbf{2 d}, \mathbf{3 d}, \mathbf{3 e}$, and $\mathbf{4 k}$ displayed another oxidation wave that in all cases was irreversible (shown in parentheses in Table 1). This is believed to arise from oxidation of the amino functionality present on the aromatic ring. This functional group has been shown to undergo oxidation under similar conditions. ${ }^{7}$

On the basis of the experimental results, it can be seen that for the unsubstituted ring systems, the order of oxidation from

(7) Korbi, B. H.; Tapsoba, I.; Benkhoud, M. L.; Boujlel, K. J. Electroanal. Chem. 2004, 571, 241.

(8) Nicholson, R. S. Anal. Chem. 1965, 37, 1351.

The redox potentials of the nitroxides shown in Scheme 2 were determined by cyclic voltammetry in acetonitrile with use of a platinum electrode and are listed in Table 1. Typical 
SCHEME 4. Synthesis of Isoindoline Derivatives $4 \mathrm{e}$ and $4 \mathrm{f}$<smiles>COc1ccc2c(c1)C(C)(C)N([O-])C2(C)C</smiles><smiles>CC1(C)NC(C)(C)c2cc(Br)c(Br)cc21</smiles><smiles>COC(=O)CO</smiles>

SCHEME 5. Synthesis of Isoindoline Derivatives $4 d$ and $4 i$

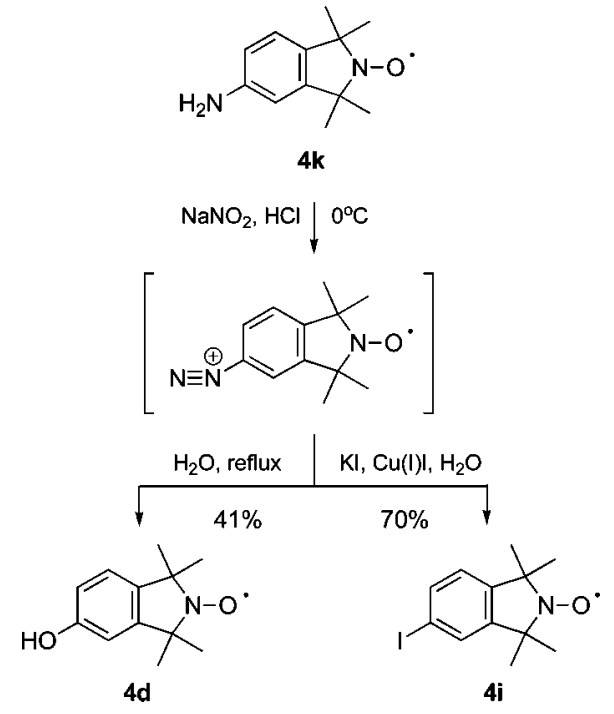

most easily oxidized to least easily oxidized is piperidine (2a, $0.577 \mathrm{~V}) \gg$ azaphenalene $(\mathbf{3 a}, 0.736 \mathrm{~V})>$ isoindoline $(\mathbf{4 a}, 0.771$ V). As described previously, ${ }^{5}$ the 6 -membered piperidine and azaphenalene derivatives are more easily oxidized than the 5-membered isoindoline derivatives. This probably arises from the greater flexibility of the 6-membered ring, which allows the nitrogen center to planarize more easily on oxidation (and pyramidalize more easily upon reduction). However, the differences between the piperidine and azaphenalene derivatives are more difficult to explain, as structural studies ${ }^{9-11}$ suggest that the piperidine and azaphenalene rings may have similar flexibilities at nitrogen. In our previous theoretical study of nitroxides in water, ${ }^{5}$ it was found that azaphenalenes were actually more easily oxidized than the piperidine derivatives, a result that we attributed to the ability of the aromatic ring of the azaphenalene to stabilize the cation, by helping to delocalize the positive charge. As seen in Figure 2, calculations indicated a significant interaction between the aromatic rings of the azaphenalene and the nitrogen center in the cation, but not in the reactant radical, giving the expectation of a net stabilizing effect on the oxidation potential of the azaphenalenes. Similar results are presented here for the calculation of the oxidation potentials of these species in this case solvated in acetonitrile (Table 2). While there is again excellent agreement between

(9) Bolton, R.; Gillies, D. G.; Sutcliffe, L. H.; Wu, X. J. Chem. Soc., Perkin Trans. 2 1993, 2049.

(10) Shen, J.; Bottle, S.; Khan, N.; Grinberg, O.; Reid, D.; Micallef, A.; Swartz, H. Appl. Magn. Reson. 2002, 22, 357.

(11) Blinco, J. P.; McMurtrie, J. C.; Bottle, S. E. Eur. J. Org. Chem. 2007, 4638 .

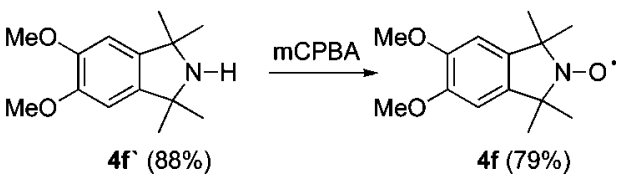

theory and experiment (the mean absolute deviation (MAD) of theory from experiment is just $50 \mathrm{mV}$ or $4.8 \mathrm{~kJ} \mathrm{~mol}^{-1}$ ) for the other classes of nitroxide studied, for the azaphenalenes there is a level of error (MAD $600 \mathrm{mV}$ ) that is unprecedented for the high level of theory used in the present work. This discrepancy will be discussed in more detail below, but could indicate that some additional factor (such as complex formation), not considered in the theoretical calculations, is contributing to the experimental results.

Functionalization of the aromatic ring systems has a small but predictable effect on the oxidation potentials, even if this occurs in a position quite remote from the nitroxide moiety. This is most obvious when oxidation potentials of monosubstituted isoindoline nitroxides are plotted against the Hammet parameters, $\sigma_{\mathrm{p}}$, an empirical constant based on the electronic effect of the subsistent ${ }^{12}$ (see Figure 3), and is consistent with our earlier theoretical observations. During preparation of this article, a paper by Manda et al. was published that showed a similar substituent-activity effect for the 5-membered pyrrolidine ring class. ${ }^{13}$

It is also observed that changing the $\mathrm{R}$ groups surrounding the nitroxide moiety of the isoindoline can affect the oxidation potential of the compounds, as seen in Figure 4. By replacing the methyl groups surrounding the nitroxide with ethyl groups there is a slightly lower oxidation potential, as the electrondonating ethyl groups can more effectively stabilize the positive charge on the cation. However, when replaced by phenyl groups, a substantially higher oxidation potential is observed. This may be the result of increased steric hindrance impacting on the ease of planarization of the cation.

The electrochemical reductions of the nitroxides were also measured by cyclic voltammetry, where possible. Typical examples are shown in Figure 5. In most cases a broad, irreversible cathodic peak is observed in an area where the solvent is also undergoing electrochemical change. This corresponds to the reduction of the nitroxide moiety to a hydroxylamine, initially formed as the nonprotonated anion. If reoxidation does occur, it is generally observed at a much higher potential than for the initial reduction (ca. 1-1.5 V) probably reflecting the oxidation of the hydroxylamine rather than the exact reversal of the reduction. When these reductions are cycled, the original nitroxide does appear to reform, based on the similarity of the subsequent reduction wave. This is consistent with the hydroxylamine oxidizing to reform the nitroxide, but may also reflect simple mass transport of new material to the electrode. The added complexity of the reductions

(12) Hansch, C.; Leo, A.; Taft, R. W. Chem. Rev. 1991, 91, 165.

(13) Manda, S.; Nakanishi, I.; Ohkubo, K.; Yakamura, H.; Matsumoto, K.; Ozawa, T.; Ikota, N.; Fukuzumi, S.; Anzai, K. Org. Biomol. Chem. 2007, 5, 3951. 


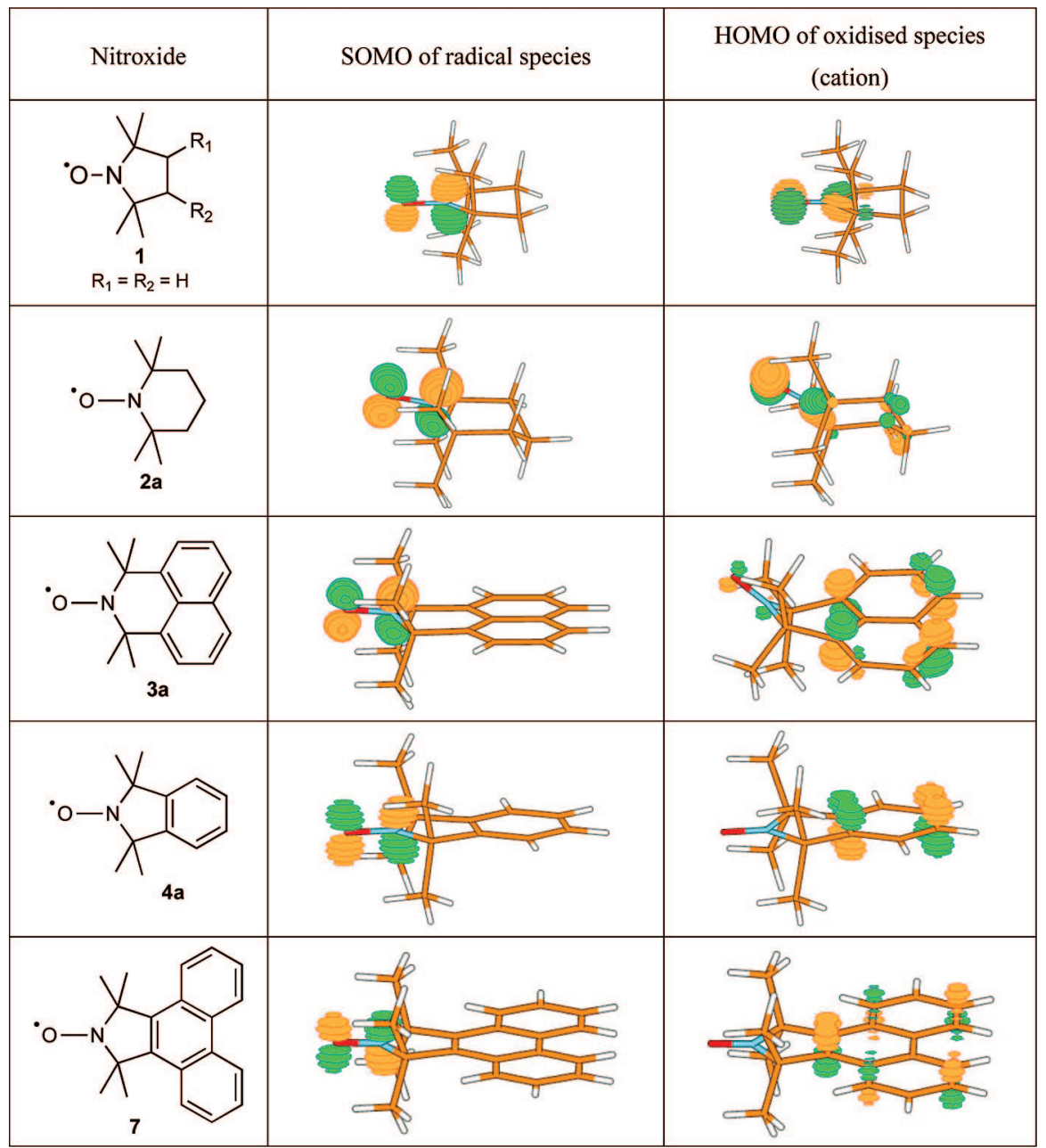

FIGURE 2. B3LYP/6-311+G(3df,2p) orbital diagrams showing the singly occupied molecular orbital (SOMO) of the parent nitroxide radicals and the highest occupied molecular orbital (HOMO) of the oxidized species.

made estimating $E^{\mathrm{o}}$ values for these measurements impractical and as such only the $E_{\mathrm{pc}}$ and $E_{\mathrm{pa}}$ (where applicable) are quoted.

\section{Theoretical Calculations}

We previously identified a computational method for calculating electrode potentials of nitroxide species and showed that it compared well to experimental values in an aqueous medium. ${ }^{5}$ Recalculating the oxidation potentials of some of the previously studied nitroxides in aceonitrile and calculating some additional species allowed us to compare a greater number of calculated species with experimental oxidation potentials. The experimental and theoretical results for the oxidation potentials are shown in Table 2 . As discussed in our previous theoretical study, ${ }^{5}$ the reduction reaction is more complicated due to protonation of the reduced species. As a result, the formal one-electron reduction potentials obtained via our calculations are not directly comparable with the irreversible half-wave potentials obtained via cyclic voltammetry, and have to be corrected for the additional chemical reactions that take place on reduction. For the one-electron reduction of nitroxides in water, eq 1 describes the relationship between the formal one-electron reduction potentials $\left(E^{\circ}\right)$ and the half-wave potentials $\left(E_{1 / 2}^{\text {rev }}\right)$ for $\mathrm{pH} 7$ in water at 298 K. ${ }^{14,15}$

(14) Kato, Y.; Shimizu, Y.; Yijing, L.; Unoura, K.; Utsumi, H.; Ogata, T. Electrochem. Acta 1995, 40, 2799.

(15) Israeli, A.; Patt, M.; Oron, M.; Samuni, A.; Kohen, R.; Goldstein, S. Free Radical Bio. Med. 2005, 38, 317.

$$
E_{1 / 2}^{\mathrm{rev}}=E^{\mathrm{o}}-\frac{R T}{F} \ln \left(K_{1} K_{2}\right)+\frac{R T}{F} \ln \left(K_{1} K_{2}+K_{1}\left[H^{+}\right]+\left[H^{+}\right]^{2}\right)
$$

where $K_{1}$ and $K_{2}$ are the acid dissociation constants of the hydroxylamine and protonated hydroxyl amine, respectively, $R$ is the universal gas constant, $F$ is the Faraday constant, and $T$ is the temperature. These corrections to the formal reduction potential are significant: in our previous study of nitroxides in water we found the calculated half-wave potentials in water differed from the calculated formal reduction potentials by over $1.65 \mathrm{~V}$, with the former showing excellent agreement (within $0.04 \mathrm{~V}$ ) with the corresponding experimental values. ${ }^{5}$ Unfortunately, there is currently no published formula describing the calculation of irreversible half-wave potentials for nitroxides in acetonitrile, and we are thus unable to make the same comparisons in the present work.

From Table 2, it is seen that the correlation between the theoretical calculations and experimental data is very high for the pyrroline, piperidine, and isoindoline ring classes. As noted above, for these species the mean absolute deviation of theory from experiment is $50 \mathrm{mV}$. The only significant outlier is the calculation for compound $\mathbf{2 d}$ (where the error is $268 \mathrm{mV}$ ). In this case, the experimental results indicate that the irreversible oxidation of the amine substituent, not considered in the theoretical calculations, is affecting the results. However, as foreshadowed above, there is an enormous and relatively systematic deviation of $600 \mathrm{mV}$ between the calculated results and experiment for the azaphenalene class 
TABLE 2. Comparison of Experimental and Theoretical Oxidation Potentials $(V)$ of the Studied Nitroxides

\begin{tabular}{ccccc}
\hline compd & exptl $E^{\mathrm{o}}$ & corrected to SHE & calcd $E^{a}$ & exptl - calcd \\
\hline $\mathbf{1}$ & 0.702 & 0.976 & 0.971 & 0.005 \\
$\mathbf{2 a}$ & 0.577 & 0.850 & 0.807 & -0.043 \\
$\mathbf{2 b}$ & 0.65 & 0.924 & 0.895 & -0.029 \\
$\mathbf{2 c}$ & 0.603 & 0.877 & 0.836 & -0.041 \\
$\mathbf{2 d}$ & 0.789 & 1.063 & 0.795 & -0.268 \\
$\mathbf{3 a}$ & 0.736 & 1.010 & 0.474 & -0.536 \\
$\mathbf{3 b}$ & 0.822 & 1.096 & $0.572^{b}$ & -0.524 \\
$\mathbf{3 c}$ & 0.902 & 1.175 & $0.705^{b}$ & -0.470 \\
$\mathbf{3 d}$ & 0.829 & 1.102 & $0.341^{b}$ & -0.761 \\
$\mathbf{3 e}$ & 0.908 & 1.182 & $0.474^{b}$ & -0.708 \\
$\mathbf{4 a}$ & 0.771 & 1.045 & 0.999 & -0.046 \\
$\mathbf{4 b}$ & 0.821 & 1.095 & $1.080^{b}$ & -0.015 \\
$\mathbf{4 c}$ & 0.849 & 1.123 & $1.167^{b}$ & 0.044 \\
$\mathbf{4 d}$ & 0.749 & 1.023 & $0.980^{b}$ & -0.043 \\
$\mathbf{4 e}$ & 0.757 & 1.030 & $0.972^{b}$ & -0.058 \\
$\mathbf{4 f}$ & 0.733 & 1.007 & $0.957^{b}$ & -0.050 \\
$\mathbf{4 g}$ & 0.825 & 1.099 & $1.061^{b}$ & -0.038 \\
$\mathbf{4 h}$ & 0.857 & 1.130 & $1.112^{b}$ & -0.018 \\
$\mathbf{4 i}$ & 0.817 & 1.091 & & \\
$\mathbf{4 j}$ & 0.875 & 1.148 & $1.142^{b}$ & -0.006 \\
$\mathbf{4 k}$ & 0.717 & 0.990 & $0.920^{b}$ & -0.070 \\
$\mathbf{5 a}$ & 0.729 & 1.003 & $0.972^{b}$ & -0.031 \\
$\mathbf{5 b}$ & 1.027 & 1.301 & & -0.124 \\
$\mathbf{6}$ & 0.816 & 1.091 & $0.967^{b}$ & -0.025 \\
$\mathbf{7}$ & 0.793 & 1.067 & $1.042^{a}$ & \\
\hline
\end{tabular}

${ }^{a}$ Calculated by using gas-phase species optimized at the G3(MP2)-RAD level with B3-LYP/6-31G(d) optimized geometries. Solvation energies were calculated by using PCM at the B3-LYP/6-31G(d) level of theory, using the SCFVAC keyword in GAUSSIAN. ${ }^{b}$ ONIOM calculations found by using core systems calculated at G3(MP2)-RAD, with the full system calculated at RMP2/6-311+G(3df,2p); using as core systems the parent (H-substituted) nitroxides.

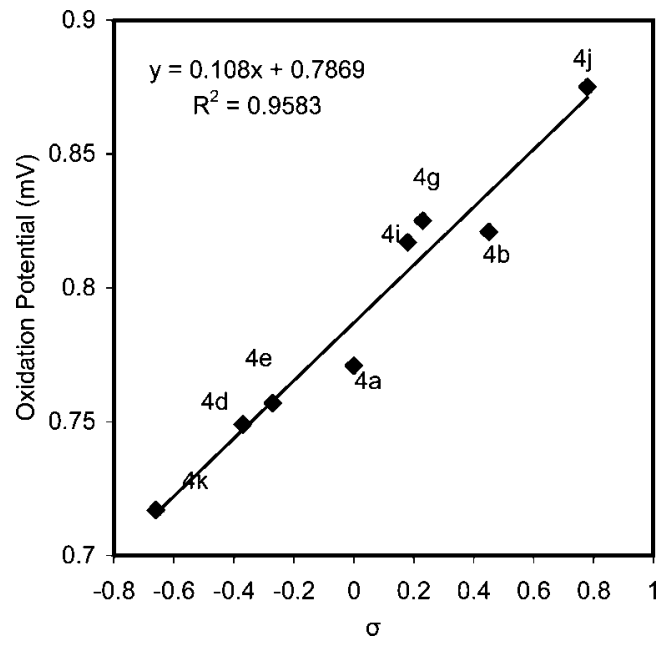

FIGURE 3. Oxidation potentials of monosubstituted isoindoline nitroxides plotted with respect to the Hammett constant of the functional group $\left(\sigma_{\mathrm{p}}\right)$.

with the theoretical calculations. This level of error is an order of magnitude higher than that observed for the other species, both in the present work and our previous theoretical study of nitroxides in water, and also in other studies of one- and two-electron oxidation and reduction potentials. ${ }^{16}$ More generally, the G3 family of computational methods has been shown to deliver "kcal accuracy" when assessed against large test sets of experimental data. ${ }^{17}$

(16) See for example: (a) Namazian, M.; Coote, M. L. J. Phys. Chem. A 2007, 111, 7227. (b) Namazian, M.; Siahrostami, S.; Coote, M. L. J. Fluorine Chem. 2007, 129, 222-225. (c) Namazian, M.; Zare, H. R.; Coote, M. L. Biophys. Chem. 2008, 132, 64 .

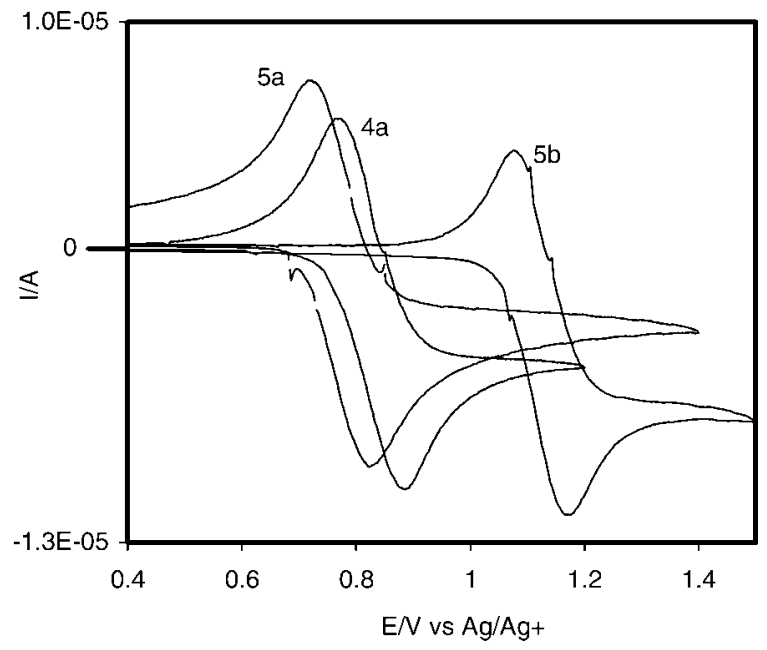

FIGURE 4. Cyclic voltammograms of the nitroxide/ $N$-oxoammonium couple of $\mathbf{5} \mathbf{a}(---), \mathbf{4 a}(-)$, and $\mathbf{5 b}(--)$.

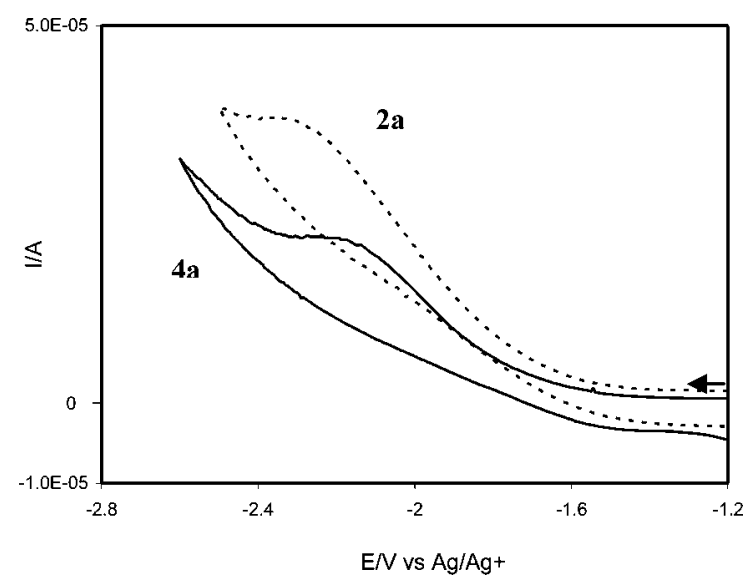

FIGURE 5. Cyclic voltammograms of the nitroxide/hydroxylamine couple of $\mathbf{2 a}$ and $\mathbf{4 a}$.

The level of error observed for the azaphenalenes in the present work is thus almost unprecedented for this high level of theory, and inconsistent with the generally good agreement between theory and experiment for the other classes of nitroxide. This would seem to suggest that the error does not arise in the electronic structure calculations themselves, but rather in some additional factor that is affecting the experimental oxidation of the azaphenalenes but is not being taken into account in the theoretical calculations. For example, as noted above, we have previously shown the reduction potentials of the nitroxides in water are strongly affected by protonation of the reduced species-once this reaction is taken into account, the reduction potentials change by over $1.65 \mathrm{~V}$ and show excellent agreement with the available experimental data. ${ }^{5}$ Protonation is clearly not the cause of the discrepancy in the oxidation potentials; however, some other physical or chemical interaction may be occurring. For example, if the azaphenalenes were to form complexes through $\pi$-stacking, this could lead to the experimentally observed oxidation potential being higher than the calculated formal one-electron oxidation potential as this would limit the concentration of free nitroxide available for oxidation. The azaphenalene nitroxides have only recently been synthesized ${ }^{11}$ and experimental data on their properties is limited; however, the discrepancy between theory and measurement is noteworthy. Further studies to explore the origin of this intriguing result are currently underway.

(17) See for example: (a) Henry, D. J.; Sullivan, M. B.; Radom, L. J. Chem. Phys. 2003, 118, 4849. (b) Curtiss, L. A.; Raghavachari, K. Theor. Chem. Acc. 2002, 108, 61 . 


\section{Conclusions}

Redox potentials determined by cyclic voltammetry were compared with calculated potentials derived by using high-level ab initio molecular orbitals theory for 25 cyclic nitroxides. Favorable comparisons were found between theoretical and experimental potentials for pyrroline, piperidine, and isoindoline ring classes. Substitutions on the nitroxide rings were correctly calculated to have a small yet predictable effect on the potentials.

The redox potentials of the novel azaphenalene nitroxides were underestimated by the calculations in all cases by at least a factor of 2. This level of error is unprecedented for the level of theory and inconsistent with the good agreement obtained for the other nitroxide classes measured. This suggests that other, as yet unknown, influences on the redox potentials of the azaphenalene ring class are not being taken into account by the theoretical model.

\section{Experimental Section}

Nitroxides 1a and $\mathbf{2 a}-\mathbf{d}$ were purchased from commercial suppliers and used as received. Nitroxides $\mathbf{3 a}, \mathbf{4 a}, \mathbf{4 b}, \mathbf{4 g}, \mathbf{4 h}, \mathbf{4 i}$, $\mathbf{4 j}, \mathbf{4 k}, \mathbf{5 a}$, and $\mathbf{5 b}$ and precursors $3 \mathbf{a}^{\prime}$ and $\mathbf{4} \mathbf{h}^{\prime}$ were synthesized via published procedures. ${ }^{10,11,18-21}$ The complete synthetic details for the nitroxides $\mathbf{4 c}, \mathbf{6}$, and $\mathbf{7}$ will be published in an article currently under preparation.

The electrochemical experiments were conducted in a sealed, three-electrode glass cell, controlled by a Princeton Applied Instruments 273A Potentiostat galvanostat. A platinum wire and solid $\mathrm{Ag} / \mathrm{Ag}^{+}$electrode were used as a counter and reference electrode, respectively. A platinum electrode with a disk radius of $1 \mathrm{~mm}$ was used as the working electrode. Redox potentials were measured in $\mathrm{MeCN}$, which was refluxed over $\mathrm{CaH}$ and distilled under argon prior to use. The concentration of nitroxides used for the experiments was $1-5 \mathrm{mM}$. The supporting electrolyte was 0.1 M tetrabutylammonium tetrafluoroborate (TBAF). TBAF had been recrystallized and dried under vacuum prior to use. Before collecting the cyclic voltammograms, molecular sieves were added to the cell to minimize water present and the solution bubbled for $15 \mathrm{~min}$ with UHP argon to remove oxygen. The cyclic voltammograms were collected at room temperature at potential sweep rates of $0.05,0.1$, $0.15,0.2$, and $0.25 \mathrm{~V} \mathrm{~s}^{-1}$ for the oxidation potentials and $0.2 \mathrm{~V} \mathrm{~s}^{-1}$ for the reduction potentials. The ferrocene/ferrocenium redox couple was $E^{\mathrm{o}}=0.350 \mathrm{~V}$ vs this reference electrode and was used as a calibration standard. Potentials corrected to SHE were calculated by using conversion constants listed by Pavlishchuk et al. ${ }^{22}$

Synthesis of 2-Benzyl-1,1,3,3-tetramethyl-6-nitro-2,3-dihydro2-azaphenalene (3b'). The protected amine 2-benzyl-1,1,3,3-tetramethyl-2,3-dihydro-2-azaphenalene 3a' (200 mg, $0.64 \mathrm{mmol}$ ) was dissolved in glacial $\mathrm{AcOH}$ (ca. $10 \mathrm{~mL}$ ) and the mixture was stirred. This solution was immersed in an ice/water bath and $98 \% \mathrm{H}_{2} \mathrm{SO}_{4}$ ( $2 \mathrm{~mL}$ ) was added slowly, but at a rate sufficient to prevent the liquid from freezing. $\mathrm{HNO}_{3}(0.5 \mathrm{~mL}, 70 \%)$ was then added slowly and the solution was allowed to stir in the ice/water bath for ca. 10 min. The mixture was then stirred at room temperature for ca. $2.5 \mathrm{~h}$. The reaction was worked up by its slow addition (with stirring) to cold $10 \% \mathrm{NaOH}(250 \mathrm{~mL})$ immersed in an ice bath. The resulting suspension was extracted with $\mathrm{Et}_{2} \mathrm{O}$. The combined extracts were washed with brine, dried with $\mathrm{Na}_{2} \mathrm{SO}_{4}$, and evaporated to dryness

(18) (a) Micallef, A. S.; Bott, R. C.; Bottle, S. E.; Smith, G.; White, J. M.; Mastuda, K.; Iwamura, H. J. Chem. Soc., Perkin Trans. 2 1999, 65. (b) Griffiths, P. G.; Moad, G.; Rizzardo, E.; Solomon, D. H. Aust. J. Chem. 1983, 36, 397. (19) Reid, D. A.; Bottle, S. E.; Micallef, A. S. Chem. Commun. 1998, 1907

(20) Sato, H.; Kathirvelu, V.; Fielding, A.; Blinco, J. P.; Micallef, A. S.; Bottle, S. E.; Eaton, S. S.; Eaton, G. R. Mol. Phys. 2007, 105, 2137.

(21) Fairfull-Smith, K. E.; Blinco, J. P.; Keddie, D. J.; George, G. A.; Bottle, S. E. Macromolecules 2007, 41, 1577.

(22) Pavlishchuk, V. V.; Addison, A. W. Inorg. Chim. Acta 2000, 298, 97. yielding 2-benzyl-1,1,3,3-tetramethyl-6-nitro-2,3-dihydro-2-azaphenalene, $\mathbf{3} \mathbf{b}^{\prime}$, as a bright orange crystalline solid (226 mg, 99\%). Recrystallization from EtOH gave bright orange prisms (mp $\left.145-147{ }^{\circ} \mathrm{C}\right) .{ }^{1} \mathrm{H}$ NMR $\left(400 \mathrm{MHz}, \mathrm{CDCl}_{3}\right) \delta 1.58(12 \mathrm{H}, \mathrm{d}, J=$ $2.3 \mathrm{~Hz}), 4.29(2 \mathrm{H}, \mathrm{s}), 7.18(1 \mathrm{H}, \mathrm{m}), 7.28(2 \mathrm{H}, \mathrm{m}), 7.44(2 \mathrm{H}, \mathrm{d}, J$ $=7.1 \mathrm{~Hz}), 7.51(1 \mathrm{H}, \mathrm{d}, J=8.2 \mathrm{~Hz}), 7.61(2 \mathrm{H}, \mathrm{dd}, J=7.6,1.2$ $\mathrm{Hz}), 7.73(1 \mathrm{H}, \mathrm{dd}, J=7.6,8.2 \mathrm{~Hz}), 8.23(1 \mathrm{H}, \mathrm{d}, J=8.2 \mathrm{~Hz}), 8.50$ $(1 \mathrm{H}, \mathrm{d}, J=8.8,1.2 \mathrm{~Hz}) ;{ }^{13} \mathrm{C}$ NMR $\left(75 \mathrm{MHz}, \mathrm{CDCl}_{3}\right) \delta 48.4,58.7$, $119.9,120.9,122.9,123.6,125.3,126.0,126.1,126.5,128.1,128.9$, 144.0, 144.7, 150.6. HRMS (EI) $\mathrm{m} / z 359.1175$ (0.1 ppm from the calculated value for $\mathrm{C}_{23} \mathrm{H}_{23} \mathrm{~N}_{2} \mathrm{O}_{2}$ (molecular ion $-\mathrm{H}$ ))

Synthesis of 1,1,3,3-Tetramethyl-6-nitro-2,3-dihydro-2-azaphenalene-2-yloxyl (3b). The benzylated amine $\mathbf{3 b}^{\prime}(120 \mathrm{mg}, 0.33$ mmol) was dissolved in $25 \mathrm{~mL}$ of dichloromethane $\left(\mathrm{CH}_{2} \mathrm{Cl}_{2}\right)$. To this was added $50 \% \mathrm{~m}$-chloroperbenzoic acid (228 mg, $1.32 \mathrm{mmol}$ ) with stirring at room temperature under a normal atmosphere. The solution was then stirred for $24 \mathrm{~h}$, replacing any dichloromethane lost to evaporation. After $24 \mathrm{~h}$ the reaction mixture was washed with $50 \mathrm{~mL}$ of saturated sodium bicarbonate solution, followed by $25 \mathrm{~mL}$ of brine, then dried over sodium sulfate, next the solvent was evaporated to produce an orange oil. Purification by flash column chromatography (silica gel, $100 \% \mathrm{CH}_{2} \mathrm{Cl}_{2}$ ) afforded 170 $\mathrm{mg}$ of 1,1,3,3-tetramethyl-6-nitro-2,3-dihydro-2-azaphenalene-2yloxyl, 3b, as a orange/red solid (90\% yield) (mp $\left.171-173{ }^{\circ} \mathrm{C}\right)$. NMR gave a broad amorphous spectrum typical of paramagnetically broadened nitroxide. HRMS (EI) $\mathrm{m} / z 285.1238$ ( -0.4 ppm from the calculated value for $\mathrm{C}_{16} \mathrm{H}_{17} \mathrm{~N}_{2} \mathrm{O}_{3}$ ). Found: $\mathrm{C}, 71.89 ; \mathrm{H}, 7.09$ : $\mathrm{N}$, 9.76. $\mathrm{C}_{16} \mathrm{H}_{17} \mathrm{~N}_{2} \mathrm{O}_{3}$ requires: $\mathrm{C}, 71.81 ; \mathrm{H}, 7.09$ : $\mathrm{N} 9.85$.

Synthesis of 2-Benzyl-1,1,3,3-tetramethyl-6,7-dinitro-2,3-dihy-

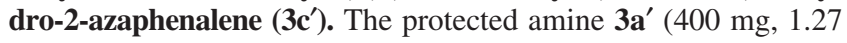
mmol) was dissolved in glacial AcOH (ca. $10 \mathrm{~mL}$ ) and stirred. The solution was immersed in an ice/water bath and $98 \% \mathrm{H}_{2} \mathrm{SO}_{4}(8$ $\mathrm{mL}$ ) was added slowly, but at a rate sufficient to prevent the liquid from freezing. $\mathrm{HNO}_{3}(2 \mathrm{~mL}, 70 \%)$ was then added slowly and the solution was stirred in the ice/water bath for ca. $10 \mathrm{~min}$. The mixture was then stirred at $60{ }^{\circ} \mathrm{C}$ for ca. $6 \mathrm{~h}$. The reaction was worked up by its slow addition (with stirring) to cold $10 \% \mathrm{NaOH}(250 \mathrm{~mL})$ immersed in an ice bath. The resulting suspension was extracted with $\mathrm{Et}_{2} \mathrm{O}$. The combined extracts were washed with brine, dried with $\mathrm{Na}_{2} \mathrm{SO}_{4}$, and evaporated to dryness. This was then subjected to flash column chromatography (silica gel, 100\% toluene) yielding the monosubstituted $\mathbf{3} \mathbf{b}^{\prime}$ as a bright orange crystalline solid (146 $\mathrm{mg}, 32 \%)$ and the disubstituted 2-benzyl-1,1,3,3-tetramethyl-6,7dinitro-2,3-dihydro-2-azaphenalene, 3c' (185 mg, 36\%). Recrystallization from EtOH gave bright orange prisms of $\mathbf{3} \mathbf{c}^{\prime}(\mathrm{mp}$ 229-230 $\left.{ }^{\circ} \mathrm{C}\right) .{ }^{1} \mathrm{H}$ NMR (400 MHz, $\left.\mathrm{CDCl}_{3}\right) \delta 1.61(12 \mathrm{H}, \mathrm{s}), 4.29$ $(2 \mathrm{H}, \mathrm{s}), 7.20(1 \mathrm{H}, \mathrm{m}), 7.29(2 \mathrm{H}, \mathrm{m}), 7.41(2 \mathrm{H}, \mathrm{m}), 7.68(2 \mathrm{H}, \mathrm{d}, J$ $=8.2 \mathrm{~Hz}), 8.30(2 \mathrm{H}, \mathrm{d}, J=8.2 \mathrm{~Hz}) ;{ }^{13} \mathrm{C} \mathrm{NMR}\left(75 \mathrm{MHz}, \mathrm{CDCl}_{3}\right)$ $\delta 48.3,59.1,116.9,122.1,126.2,126.25,126.4,127.2,128.2$, 143.89, 143.93, 150.2; HRMS (EI) $\mathrm{m} / \mathrm{z} 404.1613$ (0.7 ppm from the calculated value for $\mathrm{C}_{23} \mathrm{H}_{22} \mathrm{~N}_{3} \mathrm{O}_{4}$ (molecular ion $-\mathrm{H}$ )).

Synthesis of 1,1,3,3-Tetramethyl-6,7-dinitro-2,3-dihydro-2-azaphenalene-2-yloxyl (3c). The amine 3c' (140 mg, $0.592 \mathrm{mmol}$ ) was dissolved in $25 \mathrm{~mL}$ of $\mathrm{CH}_{2} \mathrm{Cl}_{2}$. To this was added $50 \% \mathrm{~m}$ chloroperbenzoic acid (408 mg, $2.37 \mathrm{mmol}, 4$ equiv) with stirring at room temperature under a normal atmosphere. The solution was then stirred for $24 \mathrm{~h}$, replacing any dichloromethane lost to evaporation. After $24 \mathrm{~h}$ the reaction mixture was washed with saturated sodium bicarbonate solution and dried over $\mathrm{Na}_{2} \mathrm{SO}_{4}$, then the solvent was evaporated to produce a red solid. Purification by flash column chromatography (silica gel, $100 \% \mathrm{CH}_{2} \mathrm{Cl}_{2}$ ) afforded $74 \mathrm{mg}$ of 1,1,3,3-tetramethyl-6,7-dinitro-2,3-dihydro-2-azaphenalene-2-yloxyl, 3c, as a deep red crystalline solid. Recrystallization from EtOH gave ruby red cubes (74 mg, 65\% yield) (mp 202-203 ${ }^{\circ} \mathrm{C} \mathrm{dec}$ ). NMR gave a broad amorphous spectrum. HRMS (EI) $\mathrm{m} / \mathrm{z}$, $330.1092\left(0.6 \mathrm{ppm}\right.$ from the calculated value for $\left.\mathrm{C}_{16} \mathrm{H}_{16} \mathrm{~N}_{3} \mathrm{O}_{5}\right)$. Found: $\mathrm{C}, 57.89 ; \mathrm{H}, 4.75 ; \mathrm{N}, 12.60 . \mathrm{C}_{16} \mathrm{H}_{16} \mathrm{~N}_{3} \mathrm{O}_{5}$ requires: $\mathrm{C}, 58.18$; $\mathrm{H}, 4.88 ; \mathrm{N}, 12.72$. 
Synthesis of 1,1,3,3-Tetramethyl-6-amino-2,3-dihydro-2-azaphenalene-2-yloxyl (3d). The nitroxide 3b (170 mg, $0.60 \mathrm{mmol})$ was dissolved in EtOH $(50 \mathrm{~mL})$ and hydrogenated at ca. 20 psi $\mathrm{H}_{2}$ over $10 \% \mathrm{Pd} / \mathrm{C}(50 \mathrm{mg})$ in a Parr hydrogenator for $2 \mathrm{~h} . \mathrm{PbO}_{2}(50$ $\mathrm{mg}, 2.1 \mathrm{mmol}$ ) was added and the suspension swas tirred vigorously in air for ca. $15 \mathrm{~min}$ before being filtered. Evaporation of the solvent yielded 1,1,3,3-tetramethyl-6-amino-2,3-dihydro-2-azaphenalene2-yloxy,1 3d, as a orange crystalline solid (120 mg, 79\%). Recrystallization from $\mathrm{MeOH}$ gave orange needles (mp 112-114 ${ }^{\circ} \mathrm{C}$ dec). NMR gave a broad amorphous spectrum. HRMS (EI) $\mathrm{m} / \mathrm{z}$ $255.1495 \quad(-0.9 \mathrm{ppm}$ from the calculated value for $\mathrm{C}_{16} \mathrm{H}_{19} \mathrm{~N}_{2} \mathrm{O}$ ).(Found: C, 75. 05; H, 7.49; N, 10.85. $\mathrm{C}_{16} \mathrm{H}_{19} \mathrm{~N}_{2} \mathrm{O}$ requires: $\mathrm{C}, 75.26 ; \mathrm{H}, 7.50 ; \mathrm{N}, 10.97$.

Synthesis of 6-(Dimethylamino)-1,1,3,3-tetramethyl-2,3-dihydro2-azaphenalene-2-yloxyl (3e). The amine nitroxide 3d (150 mg, 0.59 $\mathrm{mmol}), \mathrm{NaH}$ (125 mg, $5.2 \mathrm{mmol})$, and $\mathrm{MeI}(20 \mathrm{~mL})$ were combined in a sealed reaction vessel and the mixture was stirred at $65^{\circ} \mathrm{C}$ for $96 \mathrm{~h}$, protected from the light. The mixture was then cooled and water was added carefully with continuous stirring to consume excess $\mathrm{NaH}$ (Caution: violent reaction). Additional water (ca. 50 $\mathrm{mL})$ and $\mathrm{CHCl}_{3}(50 \mathrm{~mL})$ were then added, the mixture was shaken, and the organic phase was separated. The solution was washed with $25 \mathrm{~mL}$ of brine and dried over sodium sulfate, then the solvent was evaporated to produce a brown solid. Purification by flash column chromatography (silica gel, $100 \% \mathrm{CH}_{2} \mathrm{Cl}_{2}$ ) afforded 6-(dimethylamino)-1,1,3,3-tetramethyl-3-dihydro-2-azaphenalene-2-ylox$\mathrm{yl}, \mathbf{3 e}$, as a golden crystalline solid (164 mg, 98\%) (mp 122-123 ${ }^{\circ} \mathrm{C}$ ). HRMS (EI) $\mathrm{m} / \mathrm{z} 283.1810$ ( $-0.1 \mathrm{ppm}$ from the calculated value for $\mathrm{C}_{18} \mathrm{H}_{23} \mathrm{~N}_{2} \mathrm{O}$ ). Found: C, 76.28; H, 8.33; N, 9.82. $\mathrm{C}_{18} \mathrm{H}_{23} \mathrm{~N}_{2} \mathrm{O}$ requires: $\mathrm{C}, 76.29 ; \mathrm{H}, 8.18 ; \mathrm{N}, 9.89$.

Synthesis of 5-Methoxy-1,1,3,3-tetramethylisoindolin-2-yloxyl (4e). Nitroxide 4g (1.5 g, $5.6 \mathrm{mmol})$ and copper iodide $(0.218 \mathrm{~g}$, $1.1 \mathrm{mmol}$ ) were added to a solution of $\mathrm{MeONa} / \mathrm{MeOH}(5 \mathrm{M}, 7.5$ $\mathrm{mL})$ and ethyl acetate $(0.327 \mathrm{~mL}, 3.3 \mathrm{mmol})$. This mixture was refluxed for $14 \mathrm{~h}$, allowed to return to room temperature, and then poured onto ice. Extraction of the aqueous phase was performed with $\mathrm{Et}_{2} \mathrm{O}$, then the organics were separated, washed with brine, and dried over $\mathrm{Na}_{2} \mathrm{SO}_{4}$. After evaporation of the solvent under reduced pressure, the product was purified by column chromatography (silica gel, $\left.100 \% \mathrm{CHCl}_{3}\right)$ to give a yellow solid $(0.877 \mathrm{~g}$, $71 \%$ ). Recrystallization from hexane produced fine yellow needles of 5-methoxy-1,1,3,3-tetramethylisoindolin-2-yloxyl (mp 95-97 ${ }^{\circ} \mathrm{C}$ ). HRMS (EI) $\mathrm{m} / \mathrm{z}, 220.1340$ (1.1 ppm from the calculated value for $\mathrm{C}_{13} \mathrm{H}_{18} \mathrm{NO}_{2}$ ). Found: $\mathrm{C}, 70.86 ; \mathrm{H}, 8.18 ; \mathrm{N}, 6.36 . \mathrm{C}_{13} \mathrm{H}_{18} \mathrm{NO}_{2}$ requires: $\mathrm{C}, 70.88 ; \mathrm{H}, 8.24 ; \mathrm{N}, 6.36$.

Synthesis of 5,6-Dimethoxy-1,1,3,3-tetramethylisoindoline (4f'). A solution of $\mathbf{4 h}^{\prime}(300 \mathrm{mg}, 0.9 \mathrm{mmol})$ in anhydrous $N, N$ dimethylformamide $(1.0 \mathrm{~mL})$ was added to a solution of $\mathrm{MeONa} /$ $\mathrm{MeOH}$ (5 M, $2 \mathrm{~mL}$ ). To this solution was added copper iodide (20 $\mathrm{mg}, 0.1 \mathrm{mmol}$ ) and the mixture was heated at $85^{\circ} \mathrm{C}$ for $24 \mathrm{~h}$. The reaction was then allowed to return to room temperature and was subsequently poured onto ice. The aqueous phase was extracted with $\mathrm{Et}_{2} \mathrm{O}$, then the organics were combined and washed with $\mathrm{H}_{2} \mathrm{O}$ and brine and dried over $\mathrm{Na}_{2} \mathrm{SO}_{4}$. The solvent was removed under reduced pressure to give a crystalline white solid $\mathbf{4 f}^{\prime}$ (187 $\mathrm{mg}, 88 \%$ ). This material had limited stability, but was shown to be of sufficient purity by NMR for the subsequent oxidation step. ${ }^{1} \mathrm{H}$ NMR (400 $\left.\mathrm{MHz}, \mathrm{CDCl}_{3}\right) \delta 1.46\left(12 \mathrm{H}, \mathrm{s}, \mathrm{CH}_{3}\right), 1.77(1 \mathrm{H}, \mathrm{br}, \mathrm{NH}), 3.91(6 \mathrm{H}$, $\left.\mathrm{s}, \mathrm{OCH}_{3}\right), 6.62(2 \mathrm{H}, \mathrm{s}, 7-\mathrm{H}$ and $4-\mathrm{H}) ;{ }^{13} \mathrm{C} \mathrm{NMR}\left(75 \mathrm{MHz}, \mathrm{CDCl}_{3}\right)$ $\delta 32.0,56.1,62.9,104.3,140.3,148.8$.

Synthesis of 5,6-Dimethoxy-1,1,3,3-tetramethylisoindolin-2yloxyl (4f). The precursor secondary amine $4 \mathbf{f}^{\prime}$ (180 $\left.\mathrm{mg}, 0.76 \mathrm{mmol}\right)$ was dissolved in $\mathrm{CH}_{2} \mathrm{Cl}_{2}(8 \mathrm{~mL})$ and cooled to $0{ }^{\circ} \mathrm{C}$. To this was added $m$-chloroperbenzoic acid $(77 \%, 223 \mathrm{mg}, 1.3$ equiv) and the solution was stirred for $20 \mathrm{~min}$ at $0{ }^{\circ} \mathrm{C}$. The reaction was then allowed to warm to room temperature, $\mathrm{H}_{2} \mathrm{O}$ was added, and the $\mathrm{CH}_{2} \mathrm{Cl}_{2}$ layer was washed with $2 \mathrm{M} \mathrm{NaOH}$. The organic phase was then washed with brine and dried over $\mathrm{Na}_{2} \mathrm{SO}_{4}$. Evaporation of the solvent under reduced pressure afforded a yellow solid, $\mathbf{4 f}$, which was recrystallized from hexane $(152 \mathrm{mg}, 79 \%)\left(\mathrm{mp} 201-203{ }^{\circ} \mathrm{C}\right.$ dec). HRMS (EI) $\mathrm{m} / z, 250.1453$ (3.9 ppm from the calculated value for $\mathrm{C}_{14} \mathrm{H}_{20} \mathrm{NO}_{3}$ ). Found: $\mathrm{C}$ 67.15, $\mathrm{H}$ 8.19, $\mathrm{N}$ 5.47. Calcd for $\mathrm{C}_{13} \mathrm{H}_{18} \mathrm{NO}_{2}$ : C 67.18, $\mathrm{H}$ 8.05, N 5.60.

Synthesis of 5-Hydroxy-1,1,3,3-tetramethylisoindolin-2-yloxyl (4d). The nitroxide 5-amino-1,1,3,3-tetramethylisoindolin-2-yloxyl (4k) $(100 \mathrm{mg}, 0.488 \mathrm{mmol})$ was dissolved in $\mathrm{H}_{2} \mathrm{O}(0.6 \mathrm{~mL})$ and $\mathrm{HCl}(11 \mathrm{M}, 0.4 \mathrm{~mL})$ and the mixture was cooled to $0{ }^{\circ} \mathrm{C}$. To this was added $\mathrm{NaNO}_{2}\left(37 \mathrm{mg}, 0.536 \mathrm{mmol}, 1.1\right.$ equiv) in $\mathrm{H}_{2} \mathrm{O}(2.5$ $\mathrm{mL}$ ) over $30 \mathrm{~min}$ and the reaction was then stirred for a further 10 min. The reaction mixture was then diluted with $\mathrm{H}_{2} \mathrm{O}$ to ca. $40 \mathrm{~mL}$ and refluxed for $1 \mathrm{~h}$. The resultant solution was cooled and extracted with $\mathrm{Et}_{2} \mathrm{O}$. The organic phase was dried with $\mathrm{Na}_{2} \mathrm{SO}_{4}$ and the solvent was removed yielding a yellowish oil. This was then subjected to column chromatography (silica gel, 50:50 EtOAc: hexane), which yielded 5-hydroxy-1,1,3,3-tetramethylisoindolin2-yloxyl, 4d, as a pale yellow powder $(41 \mathrm{mg}, 41 \%)\left(\mathrm{mp} 235^{\circ} \mathrm{C}\right.$ dec). HRMS (EI) $\mathrm{m} / z, 206.1189$ (0.8 ppm from the calculated value for $\mathrm{C}_{12} \mathrm{H}_{16} \mathrm{NO}_{2}$ ). Found: $\mathrm{C} 69.69, \mathrm{H}$ 7.96, N 6.75. Calcd for $\mathrm{C}_{12} \mathrm{H}_{16} \mathrm{NO}_{2}$ : C 69.88, H 7.82, N 6.79.

Synthesis of 5-Iodo-1,1,3,3-tetramethylisoindolin-2-yloxyl (4i). A solution of $\mathbf{4 k}(800 \mathrm{mg}, 3.9 \mathrm{mmol})$ in $\mathrm{HCl}(3.2 \mathrm{~mL})$ and $\mathrm{H}_{2} \mathrm{O}(4.8$ $\mathrm{mL}$ ) was cooled to $0{ }^{\circ} \mathrm{C}$. To this was added $\mathrm{NaNO}_{2}(374 \mathrm{mg}, 5.42$ mmol, 1.4 equiv) in $\mathrm{H}_{2} \mathrm{O}(21 \mathrm{~mL})$ over a period of $10 \mathrm{~min}$ and the subsequent solution was allowed to stir for a further $15 \mathrm{~min}$, after which time it was added beneath the surface of a vigorously stirred cold solution of $\mathrm{KI}(3.15 \mathrm{~g}, 19 \mathrm{mmol}, \sim 5$ equiv) and $\mathrm{CuI}(74 \mathrm{mg}$, $0.39 \mathrm{mmol}, 10 \mathrm{~mol} \%)$ in $\mathrm{H}_{2} \mathrm{O}(120 \mathrm{~mL})$. The reaction mixture was transferred to a hot water bath and stirred at $40-50{ }^{\circ} \mathrm{C}$ for 20 min. The mixture was then basified and treated with $\mathrm{Na}_{2} \mathrm{~S}_{2} \mathrm{O}_{3}$ and extracted with $\mathrm{CHCl}_{3}$. The organic layer was further washed with a basic thiosulfate solution and dried with $\mathrm{Na}_{2} \mathrm{SO}_{4}$, then the solvent was removed under reduced pressure to yield a brown oil. This was subjected to column chromatography (silica gel, 30:70 EtOAc: hexane) yielding 5-iodo-1,1,3,3-tetramethylisoindolin-2-yloxyl (4i) (864 $\mathrm{mg}, 70 \%)$ as a bright yellow solid (mp 132-134 ${ }^{\circ} \mathrm{C}$ ) in agreement with literature (lit. ${ }^{21} \mathrm{mp} 132-135^{\circ} \mathrm{C}$ ).

Computational Procedures. Standard ab initio molecular orbital ${ }^{23}$ and density functional ${ }^{24}$ calculations in this work were carried out with use of GAUSSIAN $03^{25}$ and MOLPRO 2000.6. ${ }^{26}$ Geometries of all species were optimized at the B3-LYP/6-31G(d) level of theory. Frequency calculations were also carried out at the B3LYP/6-31G(d) level and scaled via the appropriate factors. ${ }^{27}$ Significant effort was taken to ensure that the optimized structure was the global (rather than merely the local) minimum energy structure by performing extensive conformational searches at the

(23) Hehre, W. J.; Radom, L.; Schleyer, P. v. R.; Pople, J. A. Ab Initio Molecular Orbital Theory; Wiley: New York, 1986.

(24) Koch, W.; Holthausen, M. C. A. Chemist's Guide to Density Functional Theory; Wiley-VCH: Weinheim, Germany, 2000.

(25) Frisch, M. J.; Trucks, G. W.; Schlegel, H. B.; Scuseria, G. E.; Robb, M. A.; Cheeseman, J. R.; Montgomery, J. A., Jr.; Vreven, T.; Kudin, K. N.; Burant, J. C.; Millam, J. M.; Iyengar, S. S.; Tomasi, J.; Barone, V.; Mennucci, B.; Cossi, M.; Scalmani, G.; Rega, N.; Petersson, G. A.; Nakatsuji, H.; Hada, M.; Ehara, M.; Toyota, K.; Fukuda, R.; Hasegawa, J.; Ishida, M.; Nakajima, T.; Honda, Y.; Kitao, O.; Nakai, H.; Klene, M.; Li, X.; Knox, J. E.; Hratchian, H. P.; Cross, J. B.; Adamo, C.; Jaramillo, J.; Gomperts, R.; Stratmann, R. E.; Yazyev, O.; Austin, A. J.; Cammi, R.; Pomelli, C.; Ochterski, J. W.; Ayala, P. Y.; Morokuma, K.; Voth, G. A.; Salvador, P.; Dannenberg, J. J.; Zakrzewski, V. G.; Dapprich, S.; Daniels, A. D.; Strain, M. C.; Farkas, O.; Malick, D. K.; Rabuck, A. D.; Raghavachari, K.; Foresman, J. B.; Ortiz, J. V.; Cui, Q.; Baboul, A. G.; Clifford, S.; Cioslowski, J.; Stefanov, B. B.; Liu, G.; Liashenko, A.; Piskorz, P.; Komaromi, I.; Martin, R. L.; Fox, D. J.; Keith, T.; Al-Laham, M. A.; Peng, C. Y.; Nanayakkara, A.; Challacombe, M.; Gill, P. M. W.; Johnson, B.; Chen, W.; Wong, M. W.; Gonzalez, C.; Pople, J. A. Gaussian 03, Revision B.03; Gaussian, Inc.: Pittsburgh, PA, 2003.

(26) Werner, H.-J.; Knowles, P. J.; Amos, R. D.; Bernhardsson, A.; Berning, A.; Celani, P.; Cooper, D. L.; Deegan, M. J. O.; Dobbyn, A. J.; Eckert, F.; Hampel, C.; Hetzer, G.; Korona, T.; Lindh, R.; Lloyd, A. W.; McNicholas, S. J.; Manby, F. R.; Meyer, W.; Mura, M. E.; Nicklass, A.; Palmieri, P.; Pitzer, R.; Rauhut, G.; Schütz, M.; Stoll, H.; Stone, A. J.; Tarroni, R.; Thorsteinsson, T. MOLPRO 200.6; University of Birmingham: Birmingham, UK, 1999.

(27) Scott, A. P.; Radom, L. J. Phys. Chem. 1996, 100, 16502. 
same level. It should also be noted that all radicals and all closedshell species considered in this study were true (local) minimum energy structures (i.e. having no imaginary frequencies). Improved gas phase energies were obtained via G3(MP2)-RAD calculations on the B3-LYP optimized structures. An ONIOM approximation that combined G3(MP2)-RAD calculations for the core (unsubstituted parent nitroxide) and ROMP2/6-311+G(3df,2p) calculations for the full system was used for larger systems. The solvation energies of each species were calculated by using the polarized continuum model PCM at the B3-LYP/6-31G(d) level, using an SCFVAC keyword in the GAUSSIAN calculation, ${ }^{28}$ and added to the gas phase free energies to give the total Gibbs energies of the species. The oxidation and reduction potentials were found from the Gibbs free energies of species by using the procedure detailed in our previous work, ${ }^{5}$ using the value of $4.52 \mathrm{~V}$ for the standard hydrogen electrode (SHE) potential in acetonitrile found recently with use of Boltzmann statistics. ${ }^{29}$ Molecular orbital diagrams showing the singly occupied molecular orbital of the parent nitroxide and the highest occupied molecular orbital of the

(28) Frisch, A.; Frisch, M. J.; Trucks, G. W. Gaussian 03 User's Reference; Gaussian, Inc.: Wallingford, CT, 2003.

(29) Kelly, C. P.; Cramer, C. J.; Truhlar, D. G. J. Phys. Chem. B 2007, 111, 408. corresponding oxidized species were calculated by using a NBO population analysis performed in GAUSSIAN at the B3-LYP/6$311+\mathrm{G}(3 \mathrm{df}, 2 \mathrm{p})$ level. Theoretical calculations were not performed for compounds $\mathbf{4 i}$ and $\mathbf{5 b}$ as, owing to their size, it was not possible to treat them with the same degree of accuracy as the other compounds in the study.

Acknowledgment. We would like to acknowledge the support of the Australian Research Council under the ARC Centres of Excellence program, CE0561607. M.L.C. and J.L.H. gratefully acknowledge generous allocations of computing time from the Australian Partnership for Advanced Computing and the Australian National University Supercomputing Facility, and the award (to J.L.H.) of an Australian Postgraduate Award.

Supporting Information Available: ${ }^{1} \mathrm{H}$ and ${ }^{13} \mathrm{C}$ NMR spectra of non-nitroxide intermediates, B3-LYP/6-31G(d) optimized geometries in the form of GAUSSIAN archive entries, and corresponding total energies. This material is available free of charge via the Internet at http://pubs.acs.org.

JO801099W 